\title{
Resistance Spectra of Wheat Cultivars and Virulence Diversity of Magnaporthe grisea Isolates in Brazil
}

\author{
Alfredo S. Urashima ${ }^{1 *}$, Norberto A. Lavorent ${ }^{2}$, Augusto C. P. Goulart ${ }^{3}$ \& Yeshwant R. Mehta $^{4}$ \\ ${ }^{1}$ Departamento de Biotecnologia Vegetal, Centro de Ciências Agrárias, Universidade Federal de São Carlos, Cx. Postal 153, \\ CEP 13600-970, Araras, SP, e-mail:alfredo@dbv.cca.ufscar.br; Departamento de Tecnologia Agroindustrial e Sócio- \\ economia Rural; ${ }^{3}$ Embrapa Agropecuária Oeste, Cx. Postal 661, CEP 79804-970, Dourados, MS; ${ }^{4}$ Instituto Agronômico do \\ Paraná, Cx. Postal 481, CEP 86001-970, Londrina, PR, Brazil
}

(Aceito para publicação em 01/06/2004)

Corresponding author: Alfredo S. Urashima

URASHIMA, A.S., LAVORENTI, N.A., GOULART, A.C.P., \& MEHTA, Y.R. Resistance spectra of wheat cultivars and virulence diversity of Magnaporthe grisea isolates in Brazil. Fitopatologia Brasileira 29:511-518. 2004.

\begin{abstract}
Seventy-two monoconidial isolates of Magnaporthe grisea were obtained from the States of Mato Grosso do Sul and Paraná. The isolates were inoculated on seedlings of 20 wheat (Triticum aestivum) cultivars under greenhouse conditions. The virulence diversity of $M$. grisea was assessed based on compatible and incompatible reactions of leaf blast on wheat cultivars. Fifty-four distinct virulence patterns were identified on test cultivars among the isolates collected from the two wheat growing States. Sixteen of these isolates corresponding to $22.2 \%$ showed similar virulence pattern.

None of the wheat cultivars was resistant to all isolates of $M$. grisea, but the cultivars differed in degree of resistance as measured by the relative spectrum of resistance (RSR) and disease index (DI). Among the cultivars the RSR ranged from 0 to $53.3 \%$ and DI from 0.4662 to 0.9662 ( 0 to 1 scale). The wheat cultivar BR18 exhibited a broad resistance spectrum in relation to the rest of the tested cultivars to the isolates of M. grisea, and can be used in wheat resistance breeding. Additional keywords: Pyricularia grisea, Triticum aestivum, resistance, control.

Espectro de resistência de cultivares de trigo e diversidade de virulência de isolados de Magnaporthe grisea no Brasil

Setenta e dois isolados monospóricos de Magnaporthe grisea foram obtidos dos estados de Mato Grosso do Sul e Paraná. Os isolados foram inoculados em plântulas de 20 cultivares de trigo (Triticum aestivum) sob condições da casa de vegetação. A diversidade da virulência de $M$. grisea foi analisada com base nas reações de compatibilidade e incompatibilidade das folhas à brusone nessas cultivares de trigo. Entre os isolados coletados nos dois estados produtores de trigo, 54 distintos padrões de virulência foram

RESUMO

identificados nessas variedades testadas. Dezesseis desses isolados, correspondendo a 22\%, apresentaram padrão de virulência similar. Nenhuma das cultivares de trigo foi resistente a todos os isolados de $M$. grisea, mas as cultivares diferiram no grau de resistência medido pelo espectro de resistência relativa (RSR) e índice de doença (DI). Entre os cultuvares RSR variou de 0 a 53,3\% e DI de 0,4662 a 0,9662 (escala de 0 a 1). A cultivar de trigo BR18 mostrou um amplo espectro de resistência em relação ao restante das cultivares, aos isolados de $M$. grisea, e pode ser útil em programas de melhoramento.
\end{abstract}

\section{INTRODUCTION}

Magnaporthe grisea (Hebert) Barr [anamorph Pyricularia grisea (Cooke) Sacc.] attacks many grasses, but rice (Oryza sativa L.) is the most important host on which it causes blast disease. In Brazil, M. grisea also causes major yield losses on wheat (Triticum aestivum L.) under natural conditions in the State of Paraná and Mato Grosso do Sul (Igarashi, 1990; Goulart \& Paiva, 2000). Blast of wheat was first reported in the northern region of Paraná in 1985 (Igarashi et al., 1986) and rapidly spread to other wheat growing regions of the country (Piccinini \& Fernandez, 1989; Goulart et al., 1990; Prabhu et al., 1992; Dos Anjos et al., 1996). Because of the lack of effective fungicides, resistant cultivars (Igarashi, 1990; Urashima \& Kato, 1994), and wide geographical

*Bolsista FAPESP JP99/12269-5 distribution of wheat blast disease (Igarashi, 1990), this has become one of the major diseases of wheat in Brazil.

The fungus produces lesions on all above-ground parts of the plant but the spike infection is the most common symptom observed in the field. On leaves, the lesions vary in shape and size, depending on the age of the plant. Usually the partially infected spikes becomes bleached, straw colored and can be clearly distinguished from the healthy part of the spike below the infected terminal part. Normally, the bleached portion of the spike does not produce grain.

As in the case of rice blast disease, the best disease management strategy for wheat blast should combine cultivar resistance with appropriate agronomic practices. The identification of resistance to blast in commercially important cultivars is an important step in developing a disease management strategy.

Commercial wheat cultivars BH1146, IAC8, IAC24, 


\section{A.S. Urashima et al.}

IAC28, IAC162 were considered resistant to $M$. grisea in a field trial in the state of Sao Paulo (Barros et al., 1989). In Mato Grosso do Sul, 'BH1146’ exhibited good resistance with less than 5\% spike infection (Goulart \& Paiva, 1992). In another study, cultivars CNT8 and Ocepar11 were reported to be immune, and 'BH1146', 'IAC27', 'Ocepar6', 'Ocepar12', 'CEP7780', 'CEP8066', and 'Iapar1' had a low percentage of head infection (Igarashi, 1990). In subsequent studies, all of these cultivars were susceptible in artificial inoculation (Igarashi, 1990; Urashima \& Kato, 1994). The differences among these results may be attributed to pathogenic variability, which emphasizes the need to test wheat cultivars for different pathogen populations in order to identify resistant cultivars. Furthermore, little information is available on virulence diversity within the wheat blast population in Brazil.

The objectives of the current study were to screen commercial wheat cultivars at the vegetative stage for resistance to isolates of M. grisea from Mato Grosso do Sul and Paraná, where wheat blast disease is a major problem, and to characterize the virulence diversity of isolates of $M$. grisea from wheat.

\section{MATERIALANDMETHODS}

\section{Host}

Twenty wheat cultivars from different breeding centers were selected because they were reported to have resistance to blast, or are officially recommended in Brazil (Igarashi et al., 1986; Barros et al., 1989; Goulart \& Paiva, 1992; Urashima \& Kato, 1994; Ata Embrapa, 2001). Seeds of the 20 cultivars were obtained from Empresa Brasileira de Pesquisa Agropecuária (Embrapa), Instituto Agronômico do Paraná (Iapar), Instituto Agronômico de Campinas (IAC), and Coooperativa Central Agropecuária de Desenvolvimento Tecnológico e Econômico (Coodetec). Four or five plants were grown in 250ml-plastic pots with unfertilized forest soil and kept in a greenhouse at 23 $\pm 5{ }^{\circ} \mathrm{C}$ until inoculation.

\section{Pathogen}

Isolates of $M$. grisea were obtained from diseased wheat spikes randomly collected from fields in the major wheat-growing areas of Mato Grosso do Sul and Paraná (Table 1). The isolates were collected from 'hot spot' locations and from cultivars widely grown in the region. Wheat fields were separated from each other by approximately $4 \mathrm{~km}$. Infected tissues were cut in small pieces, placed in petri dishes, and kept under moist condition for $24 \mathrm{~h}$ at $25^{\circ} \mathrm{C}$. Single-conidial isolations were made on potato dextrose agar (PDA) slants. For long term storage, pure cultures were grown on sterilized barley (Hordeum vulgare L.) seeds in a vial, then dried completely at $25^{\circ} \mathrm{C}$ and stored in a plastic case with silica gel at $5^{\circ} \mathrm{C}$. A total of 72 isolates were employed in the present work.

\section{Inoculation}

Inoculum was prepared from cultures grown on oatmeal agar medium (OA). Transfers were made from PDA slants onto
OA and incubated at $25{ }^{\circ} \mathrm{C}$ under continuous fluorescent illumination. After ten-11 days, plates were flooded with sterilized distilled water, and aerial mycelia were removed by gently rubbing the colony with a glass rod. The suspension was then exposed to near-ultra violet light at $22{ }^{\circ} \mathrm{C}$ for three days to induce sporulation. The conidial and mycelial suspension was filtered through two layers of cheesecloth and adjusted to $1 \mathrm{X} 10^{5}$ conidia per ml. Twenty ml of the conidial suspension with $200 \mu \mathrm{l}$ of Tween20, was sprayed on the 20 commercial wheat cultivars raised on plastic pots at the threeto four-leaf stage using an air compressor. The plants were placed in plastic bags to maintain a water-saturated atmosphere and placed in a greenhouse at $23 \pm 5^{\circ} \mathrm{C}$. After $18 \mathrm{~h}$, bags were removed and the pots were randomized on the greenhouse bench until disease assessment.

\section{Disease assessment}

Plants were examined for symptoms six-seven days after inoculation. Five phenotypic reactions were recognized: $0=$ no visible reaction; 1 = minute, pinhead-sized spots; 2 = small brown to dark brown lesions with no distinguishable centers; 3 = small eyespot shaped lesions; with grey centers; 4 = typical blast lesions, elliptical with grey centers (Valent et al., 1991). Lesion types 0,1 , and 2 were classified as resistant and lesion types 3 and 4 as susceptible. When different types of lesions were found on a single leaf, the largest lesions were considered. Four replications per cultivar were used for each fungal isolate. Four to Five seedligs were used per replication.

\section{Resistance level}

Two criteria were utilized to determine the disease resistance spectra of wheat cultivars: 1 . The level of resistance for each cultivar was evaluated using the relative spectrum of resistance (RSR) expressed by the percentage of isolates of M. grisea to which a cultivar was resistant. The percentage of isolates to which a cultivar is resistant was considered to be a relative measure of the spectrum of resistance because the quantitative nature of resistance is apparently conditioned by the presence of several to many vertical or race specific resistance genes (Ahn \& Ou, 1982), . Thus, a cultivar with resistance to the most fungal isolates was considered to have the high4est spectrum of resistance. Moreover, when wheat cultivars were inoculated with $M$. grisea isolates, they showed a range of reactions varying from none, to a few, small brown to numerous large, greyish eyespotshaped lesions.

2. A disease index (DI) used for Rhynchosporium secalis (Oud) Davis in barley by Zhang et al. (1987) was adapted and calculated as follows:

$$
D I=\frac{\sum_{j} j f_{j}}{4 \sum_{j} f_{j}}
$$

where $f_{j}=$ number of individuals in the th category. The variance of the DI was calculated by: 
Resistance spectra of wheat cultivars and virulence diversity of...

$$
V(\mathrm{DI})=\frac{\sum_{j} f_{j}\left(\sum_{j}^{j-\sum_{j} j f_{j}} / \sum_{j} f_{j}\right)^{2}}{16\left(\sum_{j} f_{j}\right)\left(\sum_{j} f_{j}-1\right)}
$$

The quantitative measurement of DI described above provides an effective mean for summarizing the resistance of a cultivar using the full range of disease scores from 0 to 4 . Values of DI can range from 0 , if every individual in an entry scores 0 , to the maximum of 1 , if every individual scores 4 .

\section{Statistical analysis}

The 95\% confidence interval (CI) was used to determine differences between DI values of different cultivars. The DI values of the two samples were considered significantly different at 5\% probability level if the 95\% CI's of the two DI's did not overlap.

\section{RESULTS}

Fifty four distinct virulence patterns were observed among the 72 isolates of $M$. grisea tested (Table 2; Table 3). Overall, 30 distinct virulence patterns were detected among the 37 isolates of M. grisea isolates from Mato Grosso do Sul and 25 different virulence pattern from the 35 isolates from Paraná. Four virulence patterns, designated 'a', 'b', 'c', 'd' were represented by more than one isolate, and the remaining 50 were each represented by one isolate. A mixture of isolates designated ' $a$ ', representing the largest number of isolates was comprised of 16 or $22.2 \%$ of the isolates and was compatible on all cultivars. These isolates were present in both States and isolated from different wheat cultivars. Mato Grosso do Sul and Paraná are among the most important wheat producing

TABLE 1 - Field designation, number of isolates, location, and wheat (Triricum aestivum) cultivar from which isolates of Magnaporthe grisea were obtained

\begin{tabular}{cclll}
\hline \hline $\begin{array}{l}\text { Field } \\
\text { designation }\end{array}$ & $\begin{array}{c}\text { Number } \\
\text { of isolate }\end{array}$ & Location - State & $\begin{array}{l}\text { Date of } \\
\text { collection }\end{array}$ & Cultivar \\
\hline PR01 & 8 & Londrina - PR & Ago/98 & OR-1 \\
PR02 & 9 & Toledo - PR & Set/98 & Ocepar22 \\
PR03 & 4 & Palotina - PR & Out/98 & OR-1 \\
PR04 & 6 & Palotina - PR & Out/98 & Ocepar22 \\
PR05 & 6 & Palotina - PR & Out/98 & Ocepar22 \\
PR06 & 1 & Cascavel - PR & Set/98 & CD104 \\
PR07 & 1 & Cascavel - PR & Set/98 & CD104 \\
MS01 & 3 & Itaporã - MS & Jul/98 & OR-1 \\
MS02 & 3 & Indápolis - MS & Jul/98 & Anahuac \\
MS03 & 2 & Itaporã - MS & Jul/98 & Embrapa10 \\
MS04 & 8 & Itaporã - MS & Jul/98 & Ocepar16 \\
MS05 & 6 & Itaporã - MS & Jul/98 & Ocepar22 \\
MS06 & 9 & Indápolis - MS & Jul/98 & BR40 \\
MS07 & 6 & Itaporã - MS & Jul/98 & BR31 \\
\hline 1PR = Pará State; MS = Mato Grosso do Sul State & \\
& & &
\end{tabular}

${ }^{1} \mathrm{PR}=$ Paraná State; MS = Mato Grosso do Sul State states of Brazil and the regions from which the pathogen was isolated in each State were separated by more than $300 \mathrm{~km}$. Virulence patterns designated 'b', 'c', 'd' were formed by two isolates each. The two isolates comprising ' $b$ ’ was found only in one city of Mato Grosso do Sul on two different cultivars (cvs. Ocepar16 and BR31). The isolates comprising ' $c$ ' and ' $d$ ' were found only in the State of Paraná; 'c' was found on the same wheat cultivar in two different cities whereas ' $d$ ' was identified in one single field of Palotina city. Isolates MS04-02, MS05-09, MS07-01, MS07-09, PR02-04, PR04-02, PR04-09, and 'b' (MS04-16, MS07-09) were virulent to all but one cultivar, but represented eight distinct virulence patterns. Seven isolates were avirulent on two cultivars and represented seven different virulence patterns. For each virulence pattern, seven to 20 cultivars were susceptible. The number of reaction patterns found in a single field varied from 1 (fields PR06 and PR07) to 8 (fields MS06, PR01 and PR02).

None of the wheat cultivars was resistant to all isolates, but the cultivars showed differences in RSR. RSR in Paraná state varied from 0.0 to $51.4 \%$ (Table 4). Cultivars Ocepar7, Embrapa10, Anahuac, and Ocepar22 were susceptible to all isolates (RSR = 0). 'Ocepar7', 'Embrapa10', 'Anahuac', 'Ocepar22', 'BR40’, 'Iapar17’, 'Frontana', 'BR11', 'IAC1003’, and ‘Ocepar15' showed RSR ranging from 0 to 17.1 indicating susceptibility to more than $80 \%$ of isolates tested. Various cultivars exhibited the same degree of resistance, 'BR31' and 'Ocepar' with RSR = 22.9, 'OR-1', 'BR17', and 'Iapar28' with $\mathrm{RSR}=20.0$, Frontana and BR11 (RSR = 8.6), and 'BR40’ and 'Iapar17' (RSR = 2.9). On the other hand, cultivar BR18 with RSR of $51.4 \%$ was the only cultivar that showed resistance to more than $50 \%$ of the isolates tested.

In Mato Grosso do Sul, cvs. BR40, Iapar17, Anahuac, and Embrapa10 were susceptible to all isolates (Table 5). Besides these cultivars, seven others (Ocepar7, Ocepar15, BR11, Frontana, Ocepar16, IAC1003, and Iapar28) showed susceptibility to more than $80 \%$ of isolates. Two cultivars showed RSR higher than 50\%, BR18 with RSR of 51.3\% and BR21 with RSR of 53.3 of isolates of $M$. grisea.

Considering the toal number of 72 isolates collected from two States, 'Anahuac' and 'Embrapa10' showed. 'BR21 and 'BR18' were resistant to most of the isolates with RSR of 53.3 and 51.3\%, respectively. Among the 20 wheat cultivars studied, 14 had RSR equal or lower than $20 \%$.

The average DI of the 40 isolates of $M$. grisea from Paraná was 0.8204 with values ranging from 0.9643 to 0.5786 (Table 4). Ten cultivars with the lowest RSR (<20\%) also had the highest DI values (higher than 0.8357). The cultivar in Paraná with the highest RSR (51.4\%) and lowest DI (0.5786) was BR18.

The average DI of 37 isolates of $M$. grisea from Mato Grosso do Sul was 0.7550. 'Embrapa10' had the highest DI (0.9662) and 'BR18' had the lowest (0.4662) (Table 5). In Mato Grosso do Sul, 'Embrapa10' and 'Anahuac' were the most susceptible cultivars with the lowest RSR and highest DI values. Cultivars BR40 and Iapar17 were also susceptible to $100 \%$ of the isolates, but had a significantly lower DI than 'Embrapa10' 
TABLE 2 - Virulence pattern of Magnaporthe grisea from Mato Grosso do Sul based on compatible and incompatible reactions on wheat (Triticum aestivum) cultivars

\begin{tabular}{|c|c|c|c|c|c|c|c|c|c|c|c|c|c|c|c|c|c|c|c|c|}
\hline \multirow[b]{2}{*}{$\begin{array}{l}\text { M. grisẹa } \\
\text { Isolate }\end{array}$} & \multicolumn{20}{|c|}{ Reaction type $^{\mathrm{y}}$} \\
\hline & 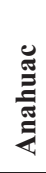 & $\stackrel{\stackrel{D}{\Xi}}{\Xi}$ & 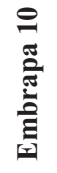 & $\frac{\bar{x}}{0}$ & $\stackrel{\infty}{\sum_{U}}$ & 吾 & $\begin{array}{l}= \\
\frac{\pi}{\infty}\end{array}$ & $\frac{\square}{\frac{\pi}{x}}$ & $\stackrel{\infty}{a}$ & $\begin{array}{l}\vec{\sim} \\
\stackrel{0}{\infty}\end{array}$ & $\begin{array}{l}\bar{m} \\
\stackrel{x}{\infty}\end{array}$ & $\begin{array}{l}\text { P } \\
\stackrel{x}{\infty}\end{array}$ & 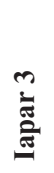 & 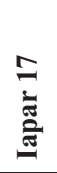 & $\begin{array}{l}\stackrel{\infty}{N} \\
\stackrel{\Xi}{\Xi} \\
\stackrel{\Xi}{\Xi}\end{array}$ & ĩ & 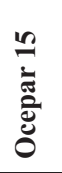 & 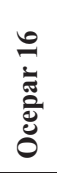 & $\begin{array}{l}\tilde{N} \\
\stackrel{\bar{\Xi}}{0} \\
\tilde{\Xi} \\
0\end{array}$ & 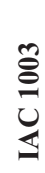 \\
\hline $\mathrm{a}$ & + & + & + & + & + & + & + & + & + & + & + & + & + & + & + & + & + & + & + & + \\
\hline $\mathrm{b}$ & + & + & + & + & - & + & + & + & + & + & + & + & + & + & + & + & + & + & + & + \\
\hline MS05-09 & + & + & + & + & + & + & + & - & + & + & + & + & + & + & + & + & + & + & + & + \\
\hline MS07-01 & + & + & + & + & + & + & + & + & + & + & + & + & - & + & + & + & + & + & + & + \\
\hline MS01-07 & + & + & + & - & + & + & + & + & + & + & + & + & - & + & + & + & + & + & + & + \\
\hline MS02-10 & + & + & + & + & + & + & + & + & - & + & + & + & + & + & + & + & + & - & + & + \\
\hline MS05-18 & + & + & + & + & + & + & + & + & + & - & + & + & - & + & + & + & + & + & + & + \\
\hline MS04-17 & + & - & + & - & + & + & - & + & + & + & + & + & + & + & + & + & + & + & + & + \\
\hline MS06-15 & + & - & + & + & + & + & + & + & - & - & + & + & + & + & + & + & + & + & + & + \\
\hline MS07-08 & + & + & + & + & + & + & + & + & - & - & + & + & - & + & + & + & + & + & + & + \\
\hline MS02-15 & + & + & + & + & + & - & + & + & - & + & + & + & - & + & + & + & + & - & + & + \\
\hline MS04-05 & + & - & + & + & - & + & + & + & + & + & - & + & - & + & + & + & + & + & + & + \\
\hline MS04-08 & + & - & + & - & - & + & + & + & + & + & + & + & - & + & + & + & + & + & + & + \\
\hline MS06-03 & + & + & + & - & + & + & + & + & - & - & - & + & + & + & + & + & + & + & + & + \\
\hline MS06-06 & + & + & + & - & + & + & + & - & + & - & - & + & + & + & + & + & + & + & + & + \\
\hline MS05-05 & + & - & + & - & + & + & + & + & - & - & + & + & - & + & + & + & + & + & + & + \\
\hline MS06-02 & + & + & + & - & + & + & + & - & - & - & - & + & + & + & + & + & + & + & + & + \\
\hline MS06-12 & + & + & + & + & - & - & + & - & - & - & + & + & + & + & + & + & + & + & + & + \\
\hline MS07-05 & + & + & + & - & + & + & + & + & + & + & - & + & + & + & + & + & + & - & - & - \\
\hline MS06-04 & + & - & + & + & - & + & - & - & - & - & + & + & + & + & + & + & + & + & + & + \\
\hline MS04-12 & + & - & + & - & - & + & + & + & - & - & - & + & + & + & + & + & + & + & + & - \\
\hline MS06-13 & + & + & + & - & + & + & - & - & - & - & - & + & + & + & + & + & + & - & + & + \\
\hline MS05-14 & + & - & + & - & - & - & + & + & - & - & + & + & - & + & - & + & + & + & + & + \\
\hline MS05-04 & + & - & + & - & - & + & + & + & - & - & - & + & - & + & - & - & + & + & - & + \\
\hline MS07-02 & + & - & + & - & - & + & + & + & - & - & - & + & - & + & - & + & - & - & - & + \\
\hline MS02-06 & + & - & + & - & - & - & + & - & - & - & - & + & - & + & - & + & + & + & - & - \\
\hline MS03-11 & + & - & + & - & - & + & + & - & - & - & - & + & - & + & - & - & + & + & - & - \\
\hline MS06-11 & + & - & + & - & - & + & + & - & - & - & - & + & + & + & - & - & - & + & - & - \\
\hline MS03-17 & + & - & + & - & - & - & + & - & - & - & - & + & - & + & - & + & - & + & - & - \\
\hline MS04-20 & + & - & + & + & - & - & - & - & - & - & - & + & - & + & + & + & - & - & - & - \\
\hline
\end{tabular}

x ' $a$ 'is comprised of isolates MS01-02, MS01-12, MS04-06, MS04-16, MS05-03, MS06-23, MS07-06, PR01-27, PR02-09, PR02-10, PR03-02, PR0303, PR04-05, PR05-04, PR05-07, PR07-05; 'b’ is comprised of isolates MS04-02, MS07-09;

y ‘+’ = compatible reaction, ‘-‘ = incompatible reaction

and 'Anahuac'. 'BR21' and 'BR18' had the highest RSR at 53.3 and 51.3, respectively.

\section{DISCUSSION}

Wheat blast disease has a recent history in Brazil. Since its first outbreak in 1985 in Northern Paraná, the disease has spread to S. Paulo, Mato Grosso do Sul, Goias and the Central Cerrado of Brazil. Yield losses in all these states are frequent although environmental conditions and other agricultural pratices are different. In the present investigation, all the wheat cultivars were susceptible to one or another isolate of $M$. grisea, with the exception of Anahuac and Embrapa10.

Even though no set of wheat cultivars has been established for race identification of $M$. grisea, most of the cultivars showed differential reaction to the fungal isolates, indicating that each one of them possesses at least one resistance gene. These cultivars were useful in examining the diversity in virulence of $M$. grisea from wheat.

The present investigation revealed that the most common group of isolates (group 'a') was formed by isolates with the ability to infect all 20 wheat cultivars. These isolates could overcome a great number of resistace genes because each of the test cultivar possessed different resistance gene against wheat blast fungus (Tables 2 and 3). The existence of isolates with this ability was observed in both wheat blast population (Mato Grosso do Sul and Paraná), in former investigation (Urashima \& Kato, 1994), and in the rice blast pathogen (Correa-Victoria \& Zeigler, 1993) demonstrating that this group of isolates is present over an extensive geographical area, retained over a large period of time, and in other pathossystems.

The virulence diversity of $M$. grisea has been attributed to mutation and parasexuality in rice (Ou, 1980; Zeigler et al., 1997; Zeigler, 1998). Recent reports, however, have not discarded the contribution of sexual recombination (Kumar et 
Resistance spectra of wheat cultivars and virulence diversity of...

TABLE 3 - Virulence pattern of Magnaporthe grisea from Paraná based on compatible and incompatible reactions on wheat (Triticum aestivum) cultivars

\begin{tabular}{|c|c|c|c|c|c|c|c|c|c|c|c|c|c|c|c|c|c|c|c|c|}
\hline \multirow[b]{2}{*}{$\begin{array}{l}\text { M. grisea } \\
\text { Isolate }^{\mathrm{x}}\end{array}$} & \multicolumn{20}{|c|}{ Reaction type $^{y}$} \\
\hline & $\begin{array}{l}\stackrel{\mathscr{E}}{E} \\
\frac{\tilde{E}}{\tilde{E}} \\
\end{array}$ & $\underset{\Xi}{ \pm}$ & 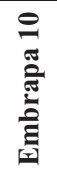 & ‡̈ & $\stackrel{\infty}{Z}$ & 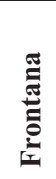 & $=$ & $\frac{1}{a}$ & $\stackrel{\infty}{\frac{\infty}{\infty}}$ & $\begin{array}{l}\vec{ָ} \\
\stackrel{\sim}{\infty}\end{array}$ & $\begin{array}{l}\bar{m} \\
\frac{1}{\infty}\end{array}$ & $\begin{array}{l}P \\
\stackrel{a}{a}\end{array}$ & 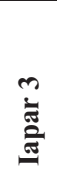 & 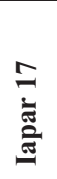 & 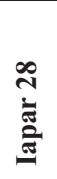 & 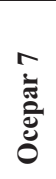 & 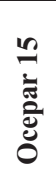 & 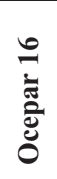 & 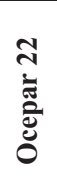 & $\underset{\Xi}{\tilde{\Xi}}$ \\
\hline $\mathrm{a}$ & + & + & + & + & + & + & + & + & + & + & + & + & + & + & + & + & + & + & + & + \\
\hline $\mathrm{c}$ & + & + & + & + & + & + & + & + & - & + & + & + & + & + & + & + & + & + & + & + \\
\hline PR02-04 & + & - & + & + & + & + & + & + & + & + & + & + & + & + & + & + & + & + & + & + \\
\hline PR04-02 & + & + & + & + & + & + & + & + & + & + & + & + & + & + & + & + & - & + & + & + \\
\hline PR04-09 & + & + & + & + & + & + & + & + & + & - & + & + & + & + & + & + & + & + & + & + \\
\hline PR02-15 & + & + & + & + & + & + & + & + & + & + & + & + & - & + & + & + & + & - & + & + \\
\hline PR03-04 & + & + & + & + & - & + & + & + & - & + & + & + & + & + & + & + & + & + & + & + \\
\hline PR04-10 & + & - & + & + & + & + & + & + & + & + & + & + & + & + & + & + & + & - & + & + \\
\hline PR06-03 & + & + & + & + & + & + & + & + & - & + & + & + & + & + & + & + & - & + & + & + \\
\hline PR01-23 & + & - & + & + & - & + & + & + & - & + & + & + & + & + & + & + & + & + & + & + \\
\hline PR01-37 & + & + & + & + & - & + & + & + & - & - & + & + & + & + & + & + & + & + & + & + \\
\hline PR02-05 & + & + & + & + & - & + & - & + & + & + & + & + & - & + & + & + & + & + & + & + \\
\hline $\mathrm{d}$ & + & + & + & + & + & + & + & - & - & - & + & + & + & + & + & + & + & + & + & + \\
\hline PR01-40 & + & + & + & + & - & + & + & + & - & + & - & + & + & + & + & + & + & - & + & + \\
\hline PR01-42 & + & + & + & + & + & + & + & - & + & + & - & + & - & + & + & + & + & - & + & + \\
\hline PR02-02 & + & + & + & + & - & + & + & + & - & - & + & + & + & + & - & + & + & + & + & + \\
\hline PR02-07 & + & - & + & - & + & + & + & + & + & + & - & + & - & + & + & + & + & - & + & - \\
\hline PR05-11 & + & + & + & - & + & + & - & + & - & - & - & + & - & + & - & + & + & + & + & + \\
\hline PR02-01 & + & + & + & - & - & - & - & + & - & - & - & + & - & + & + & + & + & + & + & + \\
\hline PR03-01 & + & - & + & - & - & + & + & - & - & + & + & + & - & - & + & + & + & + & + & - \\
\hline PR01-34 & + & - & + & + & - & - & + & + & - & - & - & + & + & + & - & + & - & - & + & + \\
\hline PR04-01 & + & - & + & + & - & + & + & - & - & + & - & - & - & + & - & + & + & + & + & - \\
\hline PR01-28 & + & - & + & - & - & + & + & + & - & - & - & + & - & + & - & + & - & - & + & + \\
\hline PR01-38 & + & - & + & - & - & + & + & - & - & - & + & + & - & + & - & + & - & - & + & + \\
\hline PR04-07 & + & + & + & - & - & - & - & - & - & - & + & + & + & + & - & + & - & + & + & - \\
\hline
\end{tabular}

x 'a'is comprised of isolates MS01-02, MS01-12, MS04-06, MS04-16, MS05-03, MS06-23, MS07-06, PR01-27, PR02-09, PR02-10, PR03-02, PR0303, PR04-05, PR05-04, PR05-07, PR07-05; 'c' is comprised of isolates PR02-08, PR05-06; 'd'is comprised of isolates PR05-02, PR05-13

y ‘'+ = compatible reaction, ' ‘' = incompatible reaction

al., 1999; Mekwtanakarn et al, 2000). This mechanism may be more likely with the wheat blast pathogen in Brazil. Studies have characterized $M$. grisea from wheat as highly fertile sexually, hermaphroditic, sexually compatible with isolates from other hosts (Urashima et al., 1993), and both MAT1-1 and MAT1-2 mating types exist in a single field (Bruno \& Urashima, 2001). The virulence diversity of isolates would also explain why some cultivars resistant in previous studies, BH1146, BR11, CNT8 (Igarashi et al, 1986; Barros et al., 1989; Goulart \& Paiva, 1992; Goulart \& Paiva, 1993) were not resistant in the present work.

Some isolates of $M$. grisea that were separated by large geographical distance (more than $300 \mathrm{~km}$ ) and were isolated from different cultivars (e.g. isolates with pathotype 'a') had the same virulence pattern, suggesting that the same avirulence genes may be involved. The presence of common pathotypes in geographically distant sites may be the result of movement of seeds infected with a specific isolate of $M$. grisea from one region to another. Fungal contamination of wheat seeds and the importance of seed transmission in leading to blast occurrence in new wheat-growing areas have been reported (Goulart \& Paiva, 1991, Urashima et al., 1999).
The virulence diversity observed in this present study is in agreement with the high degree of genetic variation detected in the wheat blast population by molecular analyses (Urashima et al., 1999).

Planting cultivars that are susceptible to a large number of isolates are a concern. Anahuac was susceptible to all isolates from both states. It was extensively cultivated at the time of the first wheat blast outbreak in 1985 and was still recommended in 1999 (Embrapa, 1999). Cultivars Embrapa10, BR40, and Ocepar22 are also cultivated in extensive areas of Mato Grosso do Sul despite their high susceptibility. Another popular cultivar, OR-1, was more susceptible to isolates in Paraná than in Mato Grosso do Sul. This difference in disease reaction could be due to the greater selection pressure for virulence in Paraná than Mato Grosso do Sul because OR-1 was introduced into Mato Grosso do Sul more recently than Paraná.

The present study did not identify any promising resistant cultivars. BR18 was the cultivar with the best performance in both states. This cultivar seems to carry a combination of several major genes for resistance reflected in the best RSR. Several genes of minor effect observed by Valent et al. (1991) in the Oryza sativa L.-M. grisea pathosystem may 
A.S. Urashima et al.

TABLE 4 - Number of Magnaporthe grisea isolates in each class of infection type, relative spectrum of resistance (RSR), and disease index (D.I.) for each wheat cultivars in Parana state

\begin{tabular}{|c|c|c|c|c|c|c|c|c|c|}
\hline \multirow{2}{*}{ Wheat Cultivar } & \multicolumn{5}{|c|}{ Infection Type* } & \multirow{2}{*}{ RSR (\%) } & \multirow{2}{*}{ D.I. } & \multirow{2}{*}{ L.L.C.I. ${ }^{1}$} & \multirow{2}{*}{ U.L.C.I. ${ }^{2}$} \\
\hline & $\mathbf{0}$ & 1 & 2 & 3 & 4 & & & & \\
\hline Ocepar7 & 0 & 0 & 0 & 7 & 28 & 0.0 & 0.9500 & 0.9442 & 0.9558 \\
\hline Embrapa 10 & 0 & 0 & 0 & 6 & 29 & 0.0 & 0.9571 & 0.9517 & 0.9626 \\
\hline Anahuac & 0 & 0 & 0 & 6 & 29 & 0.0 & 0.9571 & 0.9517 & 0.9626 \\
\hline Ocepar22 & 0 & 0 & 0 & 5 & 30 & 0.0 & 0.9643 & 0.9592 & 0.9694 \\
\hline BR40 & 0 & 1 & 0 & 8 & 26 & 2.9 & 0.9214 & 0.9124 & 0.9304 \\
\hline Iapar17 & 0 & 0 & 1 & 8 & 26 & 2.9 & 0.9286 & 0.9212 & 0.9360 \\
\hline Frontana & 1 & 0 & 2 & 8 & 24 & 8.6 & 0.8857 & 0.8735 & 0.8979 \\
\hline BR11 & 0 & 0 & 3 & 6 & 26 & 8.6 & 0.9143 & 0.9052 & 0.9234 \\
\hline IAC 1003 & 0 & 2 & 2 & 12 & 19 & 11.4 & 0.8429 & 0.8308 & 0.8549 \\
\hline Ocepar15 & 0 & 1 & 5 & 10 & 19 & 17.1 & 0.8357 & 0.8237 & 0.8477 \\
\hline Iapar28 & 2 & 1 & 4 & 10 & 18 & 20.0 & 0.7929 & 0.7768 & 0.8089 \\
\hline BR17 & 0 & 3 & 4 & 9 & 19 & 20.0 & 0.8143 & 0.8003 & 0.8283 \\
\hline OR-1 & 4 & 2 & 1 & 14 & 14 & 20.0 & 0.7286 & 0.7098 & 0.7473 \\
\hline Ocepar16 & 5 & 0 & 3 & 8 & 19 & 22.9 & 0.7571 & 0.7371 & 0.7772 \\
\hline BR31 & 0 & 3 & 5 & 14 & 13 & 22.9 & 0.7643 & 0.7509 & 0.7777 \\
\hline BH1146 & 1 & 2 & 6 & 12 & 14 & 25.7 & 0.7571 & 0.7422 & 0.7720 \\
\hline Iapar3 & 2 & 4 & 4 & 17 & 8 & 28.6 & 0.6786 & 0.6625 & 0.6947 \\
\hline BR21 & 2 & 5 & 4 & 11 & 13 & 31.4 & 0.7000 & 0.6821 & 0.7179 \\
\hline CNT8 & 2 & 4 & 7 & 11 & 11 & 37.1 & 0.6786 & 0.6614 & 0.6957 \\
\hline BR18 & 3 & 8 & 7 & 9 & 8 & 51.4 & 0.5786 & 0.5600 & 0.5972 \\
\hline
\end{tabular}

*0 = no visible reaction; 1 = minute, pinhead-sized spots; 2 = small brown to dark brown lesions with no distinguishable centers; $3=$ small eyespot shaped lesions; with grey centers; 4 = typical blast lesions, elliptical with grey centers

${ }^{1}$ L.L.C.I. $=$ lower limit of $95 \%$ confidence intervals

${ }^{2}$ U.L.C.I. = upper limit of $95 \%$ confidence intervals

TABLE 5 - Number of Magnaporthe grisea isolates in each class of infection type, relative spectrum of resistance (RSR), and disease index (D.I.) for each wheat (Triticum aestivum) cultivars in Mato Grosso do Sul state

\begin{tabular}{|c|c|c|c|c|c|c|c|c|c|}
\hline \multirow{2}{*}{ Wheat Cultivar } & \multicolumn{5}{|c|}{ Infection Type* } & \multirow{2}{*}{ RSR(\%) } & \multirow{2}{*}{ D.I. } & \multirow{2}{*}{ L.L.C.I. ${ }^{1}$} & \multirow{2}{*}{ U.L.C.I. ${ }^{2}$} \\
\hline & $\mathbf{0}$ & 1 & 2 & 3 & 4 & & & & \\
\hline BR40 & 0 & 0 & 0 & 8 & 29 & 0.0 & 0.9459 & 0.9403 & 0.9516 \\
\hline Iapar17 & 0 & 0 & 0 & 8 & 29 & 0.0 & 0.9459 & 0.9403 & 0.9516 \\
\hline Anahuac & 0 & 0 & 0 & 6 & 31 & 0.0 & 0.9595 & 0.9544 & 0.9645 \\
\hline Embrapa10 & 0 & 0 & 0 & 5 & 32 & 0.0 & 0.9662 & 0.9615 & 0.9709 \\
\hline Ocepar7 & 0 & 0 & 3 & 16 & 18 & 8.1 & 0.8514 & 0.8427 & 0.8601 \\
\hline Ocepar15 & 3 & 1 & 0 & 10 & 23 & 10.8 & 0.8311 & 0.8151 & 0.8470 \\
\hline BR11 & 0 & 0 & 4 & 15 & 18 & 10.8 & 0.8446 & 0.8354 & 0.8538 \\
\hline Frontana & 2 & 0 & 4 & 12 & 19 & 16.2 & 0.8108 & 0.7968 & 0.8248 \\
\hline Ocepar16 & 1 & 3 & 2 & 9 & 22 & 16.2 & 0.8243 & 0.8098 & 0.8389 \\
\hline IAC 1003 & 1 & 4 & 2 & 18 & 12 & 18.9 & 0.7432 & 0.7292 & 0.7573 \\
\hline Iapar28 & 1 & 2 & 4 & 18 & 12 & 18.9 & 0.7568 & 0.7438 & 0.7697 \\
\hline Ocepar22 & 1 & 1 & 6 & 5 & 24 & 21.6 & 0.8378 & 0.8239 & 0.8518 \\
\hline BR17 & 1 & 6 & 4 & 15 & 11 & 29.7 & 0.6959 & 0.6806 & 0.7113 \\
\hline BR31 & 3 & 6 & 5 & 17 & 6 & 37.8 & 0.6149 & 0.5988 & 0.6310 \\
\hline CNT8 & 6 & 3 & 6 & 13 & 9 & 40.5 & 0.6081 & 0.5894 & 0.6268 \\
\hline BH1146 & 2 & 7 & 6 & 14 & 8 & 40.5 & 0.6284 & 0.6123 & 0.6445 \\
\hline Iapar3 & 3 & 1 & 11 & 16 & 6 & 40.5 & 0.6419 & 0.6275 & 0.6563 \\
\hline OR-1 & 9 & 3 & 6 & 13 & 6 & 48.6 & 0.5270 & 0.5074 & 0.5466 \\
\hline BR18 & 12 & 3 & 4 & 14 & 4 & 51.3 & 0.4662 & 0.4460 & 0.4864 \\
\hline BR21 & 2 & 10 & 7 & 7 & 11 & 53.3 & 0.6014 & 0.5835 & 0.6192 \\
\hline
\end{tabular}

$* 0$ = no visible reaction; 1 = minute, pinhead-sized spots; 2 = small brown to dark brown lesions with no distinguishable centers; 3 = small eyespot shaped lesions; with grey centers; 4 = typical blast lesions, elliptical with grey centers

${ }^{1}$ L.L.C.I. = lower limit of $95 \%$ confidence intervals

${ }^{2}$ U.L.C.I. $=$ upper limit of $95 \%$ confidence intervals 
Resistance spectra of wheat cultivars and virulence diversity of...

also be present in this cultivar as lesion types 1 and 2, classified as an incompatible reaction because they did not sporulate when submitted to favorable conditions, as observed with different fungal isolates (Tables 4 and 5). These characteristics make it a potential donor in genetic crosses in the a search for resistant cultivar.

Meanwhile, the lack of resistant cultivars avaliable to farmers has forced them to rely on other methods of control. In recent years, wheat blast has not caused yield loss in large areas as in the past, but large yield losses have been observed in small areas in different parts of Brazil. One reason for the reduction in yield loss is delaying planting in epidemic areas until April 10 (Mehta et al., 1992). This strategy allows the heading stage to occur when the environment is drier and not favorable for blast disease. The other reason is the withdrawal of highly susceptible cultivars like Anahuac, Candeias and Ocepar7. The present work examined the performance of some new cultivars and some old ones like Iapar17, Embrapa10, BR40, and Ocepar22, which are still officially recommended (Ata Embrapa, 2001). Some of these cultivars are susceptible to blast and can be deleted from recommended list to improve the management of wheat blast in the States of Parana and Mato Grosso do Sul.

\section{ACKNOWLEDGEMENTS}

We thank M.A.R. Oliveira, P.G. Sousa, M.T. Fujino, A.R. Linhares and B.A. Welter for providing wheat seeds.

\section{LITERATURE CITED}

AHN, S.W. \& OU, S.H. Quantitative resistance of rice to blast disease. Phytopathology 72:279-282. 1982.

Ata do II Seminário Técnico de Trigo e XVI Reunião da Comissão Centro-Sul Brasileira de Pesquisa de Trigo. Londrina: Embrapa Soja, Documentos, 154. 2001.

BARROS, B.C., FELÍCIO, J.C., CAMARGO, C.E.O. \& FERREIRA FILHO, A.W.P. Reação de cultivares de trigo a brusone em condições de campo. Summa Phytopathologica 15:21. 1989. (Abstract).

BRUNO, A.C. \& URASHIMA, A.S. Inter-relação sexual de Magnaporthe grisea do trigo com a brusone de outros hospedeiros. Fitopatologia Brasileira 26:21-26. 2001.

CORREA-VICTORIA, F.J. \& ZEIGLER, R.S. Pathogenic variability in Pyricularia grisea at a rice blast 'hot spot' site. Plant Disease 77:1029-1034. 1993.

DOS ANJOS, J.R.N., DA SILVA, D.B., CHARCHAR, M.J.D. \& RODRIGUES, G.C. Ocorrência de brusone (Pyricularia grisea) em trigo e centeio na região dos cerrados do Brasil Central. Pesquisa Agropecuária Brasileira 31:79-82. 1996.

Embrapa. Recomendações da comissão centro-sul brasileira de pesquisa de trigo para 1999, Dourados, Brasil: Embrapa Agropecuária Oeste. Documentos. 1999.

GOULART, A.C.P. \& PAIVA, F.A. Controle da Pyricularia oryzae e Helminthosporium sativum pelo tratamento de sementes de trigo com fungicidas. Pesquisa Agropecuária Brasileira 26:1983-1988. 1991.

GOULART, A.C.P. \& PAIVA, F.A. Incidência da brusone
(Pyricularia oryzae) em diferentes cultivares de trigo (Triticum aestivum) em condições de campo. Fitopatologia Brasileira 17:321325. 1992.

GOULART, A.C.P. \& PAIVA, F.A. Response of wheat cultivars and breeding lines to blast (Pyricularia grisea) under field conditions, 1991. Annual Wheat Newsletter 9:109-112. 1993.

GOULART, A.C.P. \& PAIVA, F.A. Perdas no rendimento de grãos de trigo causada por Pyricularia grisea, nos anos de 1991 e 1992, no Mato Grosso do Sul. Summa Phytopathologica 26:279-282. 2000.

GOULART, A.C.P., PAIVA, F.A. \& MESQUITA, A.N. Ocorrência da brusone (Pyriculria oryzae) do trigo (Triticum aestivum) em Mato Grosso do Sul. Fitopatologia Brasileira 15:112-114. 1990.

IGARASHI, S. Update on wheat blast (Pyricularia oryzae) in Brazil. In: Saunders, D.A. (Ed.) Proceeding of the International ConferenceWheat for the nontraditional warm areas. 1990. Mexico, Mexico: CIMMYT. 1990. pp.480-483.

IGARASHI, S., UTIAMADA, C.M., IGARASHI, L.C., KAZUMA, A.H. \& LOPES, R.S. Pyricularia em trigo. 1. Ocorrência de Pyricularia sp. no estado do Paraná. Fitopatologia Brasileira 11:35152. 1986

KUMAR, J., NELSON, R.J. \& ZEIGLER, R.S. Population structure and dynamics of Magnaporthe grisea in the Indian Himalayas. Genetics 152:971-984. 1999.

MEHTA, Y.R., RIEDE, C.R., CAMPOS, L.A.C. \& KOHLI, M.M. Integrated management of major wheat diseases in Brazil: an example for the Southern Cone region of Latin America. Crop Protection 11:517-524. 1992.

MEKWATANAKARN, P., KOSITRATANA, W., LEVY, M. \& ZEIGLER, R.S. Pathotype and avirulence gene diversity of Pyricularia grisea in Thailand as determined by rice near-isogenic for major resistance genes. Plant Disease 84:60-70. 2000.

OU, S.H. Pathogen variability and host resistance of the rice blast fungus, Pyricularia oryzae Cav. Annual Review of Phytopathology 18:167-187. 1980.

PICCININI, E.C. \& FERNANDEZ, J.M.C. Ocorrência da brusone (Pyricularia oryzae) em lavouras comerciais de trigo (Triticum aestivum) no estado do Rio Grande do Sul. Fitopatologia Brasileira 14:125. 1989. (Abstract).

PRABHU, A.S., FILIPPI, M.C. \& CASTRO, N. Pathogenic variation among isolates of Pyricularia oryzae infecting rice, wheat, and grasses in Brazil. Tropical Pest Management 38:367-371. 1992.

URASHIMA, A.S., HASHIMOTO, Y., DON, L.D., KUSABA, M., TOSA, Y., NAKAYASHIKI, H. \& MAYAMA, S. Molecular analysis of the wheat blast population in Brazil with a homologue of retrotransposon MGR583. Annals of the Phytopathological Society of Japan 65:429-436. 1999.

URASHIMA, A.S., IGARASHI, S. \& KATO, H. Host range, mating type and fertility of Pyricularia grisea from wheat in Brazil. Plant Disease 77:1211-1216. 1993.

URASHIMA, A.S. \& KATO, H. Varietal resistance and chemical control of wheat blast fungus. Summa Phytopathologica 20:107-112. 1994.

VALENT, B., FARRAL, L. \& CHUMLEY, F.G. Magnaporthe grisea genes for pathogenicity and virulence identified through a series of backcrosses. Genetics 127:87-101. 1991.

ZEIGLER, R.S. Recombination in Magnaporthe grisea. Annual 


\section{A.S. Urashima et al.}

Review of Phytopathology 36:249-275. 1998.

ZEIGLER, R.S., SCOTT, R.P., LEUNG, H., BORDEOS, A.A., KUMAR, J. \& NELSON, R.J. Evidence of parasexual exchange of DNA in the rice blast fungus challenges its exclusive clonality.
Phytopathology 87:284-294. 1997.

ZHANG, Q., WEBSTER, R.K. \& ALLARD, R.W. Geographical distribution and associations between resistance to four races of Rhynchosporium secalis. Phytopathology 77:352-357. 1987. 